\title{
Reproduction of Soybean Cyst Nematode on Dry Bean Cultivars Adapted to North Dakota and Northern Minnesota
}

\author{
Susilo H. Poromarto and Berlin D. Nelson, Department of Plant Pathology, North Dakota State University, Fargo, \\ 58108-6050
}

\begin{abstract}
Poromarto, S. H., and Nelson, B. D. 2009. Reproduction of soybean cyst nematode on dry bean cultivars adapted to North Dakota and northern Minnesota. Plant Dis. 93:507-511.

Dry bean (Phaseolus vulgaris) is a host of the soybean cyst nematode (SCN; Heterodera glycines). Twenty-four cultivars of dry bean representing pinto, navy, black, and kidney bean classes were evaluated for host suitability for SCN HG type 0 in the greenhouse. Females of SCN developed normally on all dry bean cultivars in 30 days. Eggs collected from roots of dry bean plants were as effective as inoculum for soybean as eggs collected from roots of soybean. Averaged over experiments, the number of SCN females per plant was significantly lower $(P \leq$ 0.001 ) on pinto, navy, and black bean than on the susceptible soybean Lee 74 . There was no difference in the number of females between kidney bean and soybean. Numbers of females per plant differed $(P \leq 0.001)$ among navy cultivars but not among cultivars in the other three bean classes. A female index (FI $=$ the average number of females on the test plant divided by the average number of females on the susceptible soybean Lee $74 \times 100$ ) was calculated for each cultivar to evaluate resistance to SCN. FIs varied from 5 to 117, indicating a range of susceptibility in the crop. Kidney bean averaged the highest FI at 110, followed by navy, pinto, and black at $\mathrm{FI}=41,39$, and 16 , respectively. SCN is a potential threat to dry bean in the northern production area of North Dakota and northern Minnesota.
\end{abstract}

North Dakota and northern Minnesota are major dry edible bean (Phaseolus vulgaris L.) production areas, with 340,000 ha and a production value of 304 million dollars in 2007 (3). North Dakota was ranked number one in dry bean production in the United States in 2008. Navy and pinto bean constitute the major commercial production, but black turtle, cranberry, pink, red kidney, and small red bean classes are also grown in the region. Soybean cyst nematode (SCN) (Heterodera glycines Ichinohe) is a major pathogen of soybean that occurs in most soybean production areas in the United States $(12,22)$. SCN was first reported in North Dakota in 2003 (6) and the nematode is currently found in two southeastern counties, Richland and Cass, that border Minnesota. To date, only HG type 0 (13) has been identified in infested fields (6). SCN also occurs in the two Minnesota counties immediately to the east, Wilkin and Clay. Dry bean has been known as a host of SCN since it was first reported on $P$. vulgaris in Japan in the 1930s (7). However, studies on the interaction of SCN and $P$. vulgaris are limited.

Corresponding author: B. Nelson

E-mail: berlin.nelson@ndsu.edu

Accepted for publication 21 January 2009.

doi:10.1094/PDIS-93-5-0507

(C) 2009 The American Phytopathological Society
The first report of SCN in commercial production of bean in the United States was on snap bean in Illinois, where the nematode was found on chlorotic and stunted plants in the field in 1981 (14). Due to that report, snap bean lines were evaluated for susceptibility to SCN and the effect of temperature on nematode development in snap bean roots was studied $(10,11)$. There are few studies on pinto, navy, and other dry bean classes commonly grown in the North Dakota and northern Minnesota area. Smith and Young (20) studied 23 bean genotypes and found significant differences in susceptibility to SCN. Becker and Ferraz (4) examined the effect of SCN on yield of one dry bean cultivar and reported a yield reduction in greenhouse tests. Abawi and Jacobsen (1) examined the effect of egg numbers on the growth of kidney bean in greenhouse studies but reported that growth was not adversely affected. Several of these studies demonstrated that genotype of the dry bean is a major factor in reproduction of SCN on $P$. vulgaris $(11,20)$.

The objectives of this study were to evaluate reproduction of SCN on the roots of various dry bean cultivars commercially grown or being tested in the North Dakota and northern Minnesota area and determine whether cultivars were resistant or susceptible to SCN. In addition, eggs produced by SCN females on dry bean were evaluated as inoculum on soybean because there was only one report that such experiments had been conducted (7). Pre- liminary reports of this work have been published $(15,16)$.

\section{MATERIALS AND METHODS}

Dry bean genotypes. Twenty-four cultivars of dry bean representing the pinto, navy, black, and kidney bean classes were evaluated. Pinto bean cultivars were Buster, Maverick, Rally, Remington, Othello, GTS-900, Topaz, and Winchester; navy bean cultivars were Cirrus, Ensign, Mayflower, Navigator, Norstar, Premiere, Seahawk, and Vista; black bean cultivars were Condor, Eclipse, Jaguar, and T-39; and kidney bean cultivars were Cal Early, Chinook 2000, Montcalm, and Red Hawk. Soybean cv. Lee 74 was used as a susceptible control in all testing (13). Each bean class was evaluated in separate experiments.

Planting, inoculation, and cyst production. Seed were surface disinfected with $1.0 \% \mathrm{NaOCl}$ for $1 \mathrm{~min}$, rinsed with water, and germinated on seed germination paper (Anchor Paper, St. Paul, MN) for 3 days. Healthy seedlings of uniform size were transplanted into a 1-by-2.5-cm hole in autoclaved river sand in individual plastic "Cone-tainers" Type SC10 Super Cell $(3.8 \mathrm{~cm}$ in diameter, $21 \mathrm{~cm}$ in depth, volume of $164 \mathrm{ml}$; Stuewe \& Sons, Inc., Corvallis, OR). Cone-tainers were placed in autoclaved sand in plastic pots, $30.5 \mathrm{~cm}$ in diameter by $30.5 \mathrm{~cm}$ in depth (Cambro, Huntington Beach, CA), immersed in a water bath at $27 \pm 3^{\circ} \mathrm{C}$ in the greenhouse. Plants were grown for 30 days under natural and supplemental light using highpressure sodium lamps $\left(1,000 \mu \mathrm{E}^{-2} \mathrm{~m}^{-1}\right)$ for $16 \mathrm{~h} /$ day. Plants were watered daily as needed to maintain the sand at field capacity. At 14 and 21 days after planting, plants were fertilized with $3 \mathrm{ml}$ of a solution of Peters Hydro-Sol 5-11-26 (at the rate of 20 $\mathrm{ml}$ of Peters in $980 \mathrm{ml}$ of water; W. R. Grace \& Co.-Conn., Fogelsville, PA).

Soil naturally infested with SCN was collected from a soybean field in Richland County, ND. The population of SCN was identified as $\mathrm{HG}$ type 0 following the methods of Niblack et al. (13). The indicator lines and female index (FI) for the HG type classification were as follows: plant introduction (PI) 548402, FI 0.1; PI 88788, FI 0.6; PI 90763, FI 0.1; PI 437654, FI 0.2; PI 209332, FI 0.1; PI89772, FI 0.1; PI548316, FI 6.5; and Lee 74, FI 100 (average female number/plant of Lee $74=$ 570). 
The general methods of Niblack at al. (13) to inoculate plants were followed with some modifications. Cysts were extracted from the field soil with an 18-mesh (1$\mathrm{mm}$ ) sieve (VWR Scientific, West Chester, PA) nested over a 60 -mesh $(250-\mu \mathrm{m})$ sieve. Cysts were crushed with a Wheaten Potter Elvehjen Tissue Grinder (55-ml capacity) (VWR Scientific) and eggs were collected on a 200 -mesh $(75-\mu \mathrm{m})$ nested over a $500-$ mesh $(25-\mu \mathrm{m})$ sieve. A suspension of eggs in distilled water was prepared and adjusted to $1,000 \mathrm{eggs} / \mathrm{ml}$. As the seedling was transplanted into the sand, a suspension of 2,000 eggs was placed in the planting hole and the seedling was covered with sand. WatchDog 450 Data loggers with soil temperature sensors (Spectrum Technologies, Inc., Plainfield, IL) were used to monitor the temperature of the sand in the Cone-tainers. Temperatures in the sand among experiments averaged $27 \pm 1^{\circ} \mathrm{C}$, but temperature variations of 3 to $4^{\circ} \mathrm{C}$ were recorded almost daily.

Females were harvested from the roots of individual 30-day-old plants. Plants were extracted from the Cone-tainers and the root-sand masses were soaked in water. The females were washed off the roots and sieved from the water/sand mix of the root soakings using an 18-mesh nested over a 60-mesh sieve. Females from each plant were counted with a dissecting microscope. Roots were also examined with the dissecting microscope to insure that mature females were removed.

Infecting soybean with eggs from dry bean. Eggs of SCN were produced on dry bean and then inoculated onto soybean to determine if they would result in the same number of females per plant as eggs produced on soybean. Females were produced on soybean Lee 74 and two dry bean cultivars from each of the four bean classes: GTS-900 and Remington (pinto), Vista and Navigator (navy), Montcalm and Chinook (kidney), and Condor and T-39 (black). Plants were inoculated as previously described and females harvested after 30 days. Lee 74 plants were then immediately inoculated with 2,000 eggs/plant from each of the eight bean cultivars and Lee 74 . After 30 days, females were extracted and counted. In addition, the average number of eggs per female produced on the eight dry bean cultivars and Lee 74 was determined. Females from all plants of a cultivar were bulked and a random sample of females was collected, counted, and crushed, and the egg numbers were counted twice with an American Optical One-Ten microscope (Buffalo, NY).

Experimental design and analysis. The experimental design was a randomized complete block with four replications (one plant per replication) and all experiments were repeated once. All data were $\log _{10}$ transformed and a comparison of the residuals between transformed and nontransformed data was performed. Transforming the data did not improve the pattern of the residuals; thus, the nontransformed data was used in the analysis. The data from individual experiments were analyzed separately by analysis of variance (ANOVA) with SAS (SAS Institute, Cary, NC) and variances were compared between repeated experiments. The data were then combined over experiments for each bean class and analyzed by ANOVA. Least significant differences (Fisher's protected $F$ test, $\alpha=0.05)$ were calculated following significant $(P \geq 0.05) F$ tests. An FI (the average number of females on the test plant divided by the average number of females on the susceptible soybean Lee 74 $\times$ 100) (13) was calculated for each bean
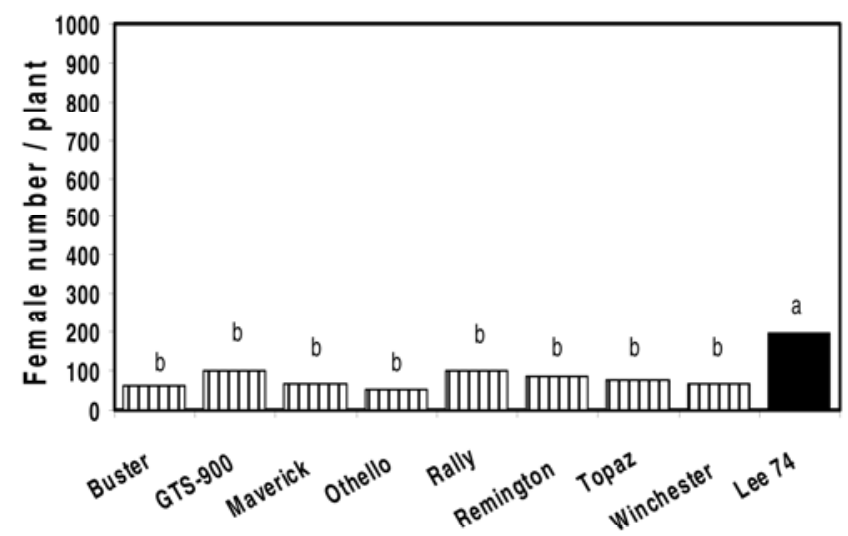

A: Pinto cultivar

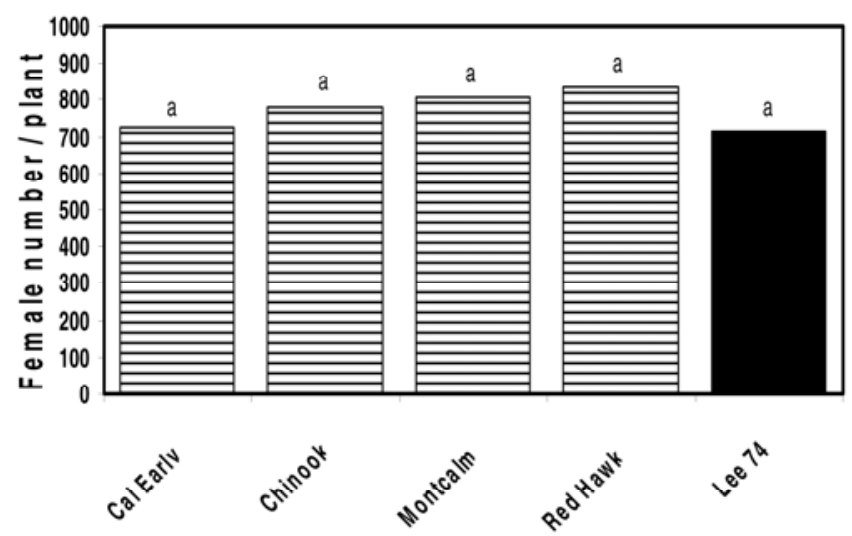

C: Kidney cultivar



B: Navy cultivar

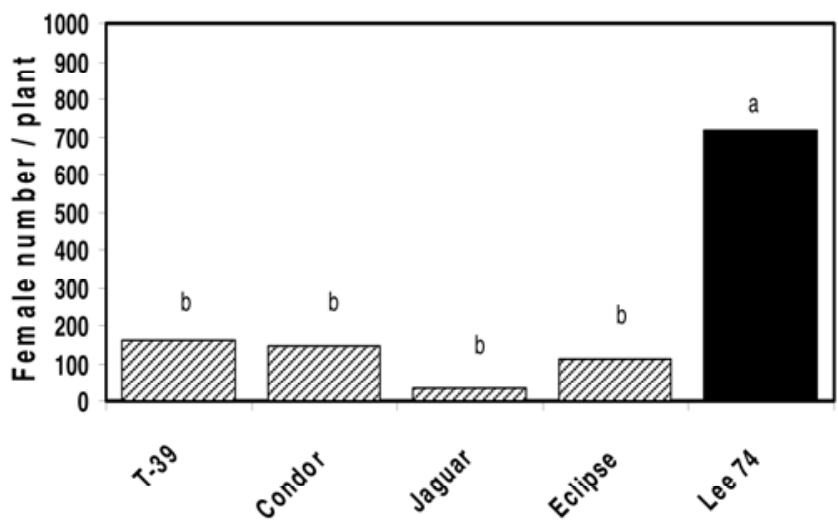

D: Black cultivar

Fig. 1. Reproduction of soybean cyst nematode HG type 0 on roots of A, pinto; B, navy; C, kidney; and D, black bean cultivars. Females were counted 30 days after inoculation of 4-day-old seedlings with 2,000 eggs/seedling in sand and incubated in a water bath at $27^{\circ} \mathrm{C}$. Data are mean number of females per plant determined from two experiments, each with four replications combined for analysis. Lee 74 is a susceptible soybean cultivar. Bars with the same letter are not significantly different (Fisher's least significant difference, $\alpha=0.05$ ). 
cultivar. By definition, the FI of Lee 74 is always 100. In experiments examining infection of soybean with eggs from dry bean, all bean cultivars were tested together in the same experiment. The data was analyzed with ANOVA as previously described.

\section{RESULTS}

SCN females developed on all 24 dry bean cultivars in the four bean classes. In 30 days, females of SCN were readily observed on bean roots with the naked eye. Some of the females had already formed brown cysts and were detached from the roots. Averaged over experiments, the number of SCN females per plant on pinto and navy bean was significantly less $(P \leq$ $0.001)$ than the 195 and 513 females per plant, respectively, on the susceptible soybean Lee 74 (Fig. 1A and B). There were no significant $(P>0.05)$ differences in number of SCN females among the pinto bean cultivars. Average number of females per pinto bean cultivar ranged from 53 to 100 per plant. There were significant differences $(P \leq 0.001)$ in numbers of females among the navy bean cultivars (Fig. 1B). Vista, for example, averaged 338 females per plant while Premiere averaged 117, the lowest among the navy cultivars. There was a significant $(P<0.01)$ experimentcultivar interaction with navy bean due to different rankings of the cultivars in the two experiments.

Reproduction on kidney bean cultivars was not significantly $(P>0.05)$ different from Lee 74 (Fig. 1C). The average number of females on kidney bean plants was 787 compared with 715 on Lee 74 . All black bean cultivars had significantly $(P \leq$ 0.001) fewer females than Lee 74 (Fig. 1D). However, there were no significant differences $(P>0.05)$ in numbers of females among the four black bean cultivars in the combined data. There was a significant $(P<0.001)$ experiment-cultivar interaction due to differences among cultivars between the first and second experiment. There was a significant $(P<0.001)$ difference in number of females between Condor and Jaguar in the second but not the first experiment. An FI was calculated to compare the reproduction of SCN among the dry bean classes (Fig. 2). Averaged over experiments, kidney bean had the largest FI at 110, while black bean had the lowest at 16. Pinto and navy bean had average FIs of 39 and 41, respectively.

Reinfection of soybean. There were no significant $(P>0.05)$ differences in the number of females on the Lee 74 plants that were inoculated with eggs produced on dry bean plants compared with plants inoculated with eggs produced on Lee 74 (Table 1). The mean number of SCN females per plant ranged from 766 to 958 . The average number of eggs per female produced on the eight bean cultivars ranged from 148 to 202, while the average on Lee 74 was 215 (Table 1).

\section{DISCUSSION}

SCN reproduced and developed normally on all 24 cultivars of dry bean plants. There were differences in numbers of SCN females that formed on the different dry bean classes grown in the North Dakota and northern Minnesota region and differences among the navy bean cultivars tested. The results are consistent with those of Smith and Young (20) and Melton et al. (11). The SCN eggs that developed on the different dry bean cultivars were as effective as inoculum on soybean as eggs from soybean. These results have implications for management of SCN in this northern area, especially where both crops are in a crop rotation. Dry bean could increase SCN populations in infested fields and growers might be less likely to notice infections on dry bean because SCN is a new disease in the region and not known to be a problem on dry bean.

There is no widely accepted method to rate dry bean cultivars for resistance or

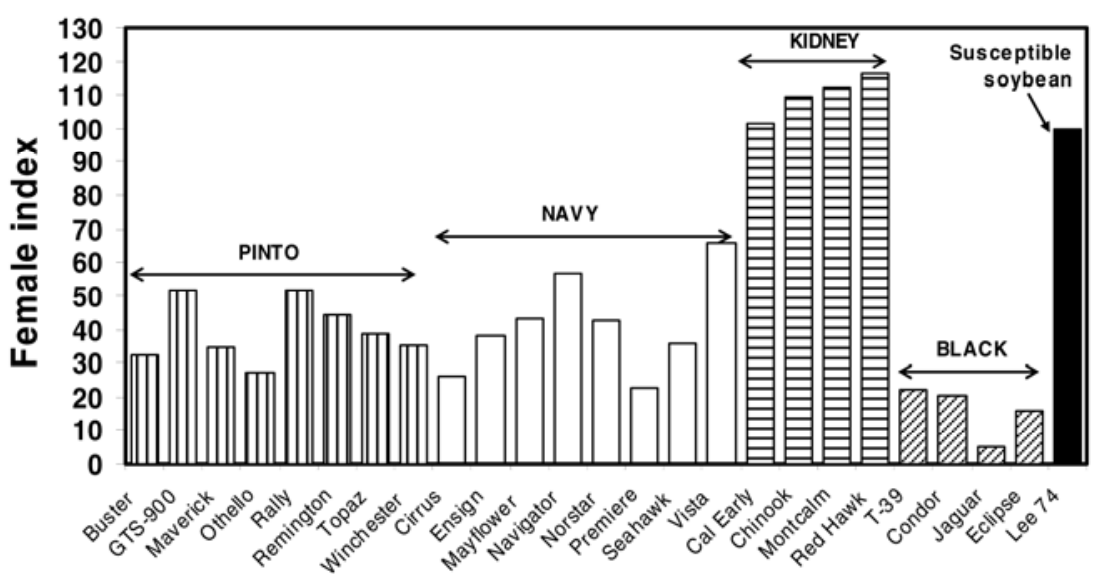

Fig. 2. Female index (FI) for reproduction of soybean cyst nematode HG type 0 on pinto, navy, kidney, and black bean cultivars. FI is the average number of females on the test plant divided by the average number of females on Lee 74 soybean $\times 100$. Lee 74 is the susceptible soybean $(F I=100)$ used as a standard for comparison. susceptibility to SCN. FI is widely used as the basis for evaluating resistance of soybean cultivars to SCN (12); the lower the FI, the greater the resistance. Because no genes for resistance to $\mathrm{SCN}$ have been identified in dry bean, an argument can be made that the term "resistance" should not be used until such genes or quantitative trait loci have been identified. However, there is a practical reason to use a resistance scale because it can provide growers with information needed to make management decisions for the control of SCN and, furthermore, it assists plant scientists in planning for future research on this potential problem. Therefore, we are adopting the FI method of Schmitt and Shannon (18) developed for soybean to classify the reaction of the dry bean cultivars tested. Smith and Young (20) also referred to this method when attempting to rate bean cultivars for resistance to $\mathrm{SCN}$; thus, there is precedent for using a scale based on FI. The Schmitt and Shannon scale categorizes soybean reactions to $\mathrm{SCN}$ as the following: FI $<10=$ resistant, FI 10 to $30=$ moderately resistant, FI 31 to $60=$ moderately susceptible, and FI $>60=$ susceptible. Whether resistance scales (12) used to classify SCN resistance in soybean can be directly applied to dry bean cultivars remains to be determined. However, reproduction on dry bean compared with a standard susceptible soybean is a reasonable approach until further information is available. The relationship of FI to potential yield loss in dry bean will not be completely understood until there is additional field research on the effect of SCN on dry bean cultivars.

Table 1. Number of females of soybean cyst nematode formed on Lee 74 soybean inoculated with eggs produced on dry bean and number of eggs per female produced on dry bean ${ }^{\mathrm{a}}$

\begin{tabular}{lcc}
\hline $\begin{array}{l}\text { Cultivar } \\
\text { (bean class) }^{\mathbf{b}}\end{array}$ & $\begin{array}{c}\text { Females/ }^{\text {plant }} \\
\text { plan }^{\mathbf{c}}\end{array}$ & $\begin{array}{c}\text { Eggs/ } \\
\text { female }^{\mathbf{d}}\end{array}$ \\
\hline Lee 74 (soybean) & 913 & 215 \\
Condor (black) & 781 & 181 \\
T-39 (black) & 783 & 165 \\
Montcalm (kidney) & 858 & 202 \\
Chinook (kidney) & 958 & 194 \\
Vista (navy) & 917 & 183 \\
Navigator (navy) & 766 & 148 \\
GTS-900 (pinto) & 862 & 186 \\
Remington (pinto) & 853 & 200 \\
\hline
\end{tabular}

${ }^{a}$ Plants inoculated with Heterodera glycines HG type 0 and incubated at $27^{\circ} \mathrm{C}$ for 30 days. Data represent means from two experiments, each with four replications combined for analysis.

b Lee 74 is the susceptible soybean for comparison.

${ }^{c}$ Lee 74 plants were inoculated with 2,000 eggs/plant produced on the respective cultivars in the lefthand column. There were no significant differences (Fisher's least significant difference, $\alpha=0.05$ ) among cultivars.

${ }^{d}$ No statistical comparison was made on egg numbers. 
Based on the FIs, all four kidney bean cultivars would be considered susceptible according to the Schmitt and Shannon scale (18). Kidney bean shows a high susceptibility to SCN compared with the other three bean classes. Abawi and Jacobsen (1) also compared a kidney bean cultivar with a susceptible soybean and reported that SCN reproduction on the kidney bean was no different from that on soybean. Pinto bean cultivars ranged from moderately resistant to moderately susceptible (FIs 27 to 52) based on the Schmitt and Shannon scale (18), whereas navy bean cultivars ranged from moderately resistant to susceptible (FIs 23 to 66). Three of the black bean cultivars were moderately resistant (FIs 16 to 22), whereas Jaguar (FI 5) was resistant. Although the black bean cultivars showed resistance to SCN, numerous developing females observed on the roots could indicate that, over an entire season of growth, $\mathrm{SCN}$ might cause more damage than is indicated by a low FI determined in a 30-day test.

The data from this research indicate that the kidney bean Montcalm was susceptible, but Smith and Young (20) reported Montcalm as resistant to moderately resistant to SCN. The average FI calculated from their data for resistance to $\mathrm{SCN}$ race two was 10, whereas the FI in this current research was 113. Smith and Young (20) used races 2, 3, 5, and 14 in their testing whereas, in the present study, we used HG type 0 , which would be equivalent to race 3 (13). The only other dry bean cultivar besides Montcalm that has been evaluated in another study is the pinto bean Maverick. The other 22 cultivars of dry bean had previously never been evaluated for SCN reproduction, nor have most cultivars adapted to the northern United States dry bean production areas. Smith and Young (20) reported that Maverick varied between moderately resistant to moderately susceptible. The average FI for Maverick calculated from their data (using SCN race two) was 33, which is similar to the FI 34 found in this current study.

There are two major gene pools of $P$. vulgaris: Middle American and Andean (19). Kidney and snap bean are from the Andean gene pool whereas pinto, navy, and black bean are from the Middle American gene pool. This current study and the report by Smith and Young (20) indicate that, within the Middle American gene pool, there are high levels of resistance to SCN. A search for resistance to SCN in dry bean should, therefore, focus on that gene pool. In contrast, the Andean gene pool appears to show the greatest susceptibility based on this study and others $(11,20)$.

There has not been a confirmed report of SCN in dry bean fields in the region, probably due to the fact that infested counties in North Dakota and northern Minnesota are south of the counties where dry bean production is concentrated. SCN likely will eventually move into those counties. The results from this study indicate that SCN can effectively reproduce on dry bean and could reduce future dry bean production in this region. The effect of SCN on growth and yield loss of dry bean has received limited study but recent reports indicate that $\mathrm{SCN}$ can reduce yield of dry bean. In Brazil, Becker and Ferraz (4) evaluated various egg levels of SCN on growth of the dry bean cv. Ouro (Middle American gene pool) in greenhouse experiments. They reported a $14.9 \%$ reduction in yield and a $40.8 \%$ reduction in root dry weight associated with 5,600 and 12,600 eggs per plant, respectively. Poromarto and Nelson (17) conducted a field study in North Dakota with the pinto bean GTS900 and soil infested with $0,5,000$ or 10,000 eggs per $100 \mathrm{~cm}^{3}$ of soil of $\mathrm{HG}$ type 0. Plant height, pod number, seed weight, and total dry weight of the aboveground plant were significantly less in plants grown in soil infested with $\mathrm{SCN}$ compared with those grown in noninfested soil. Total seed weight from infected plants was only $44 \%$ of that in the control.

Based on studies of SCN interacting with root pathogens of soybean, another potential impact of SCN on dry bean could be an increase in severity of root rots. SCN is known to increase severity of two soilborne fungal diseases of soybean: sudden death syndrome caused by Fusarium virguliforme $(9,23)$ and brown stem rot caused by Phialophora gregata (21). SCN also can cause greater severity of seedling disease caused by Phytophthora sojae in soybean (2). Dry bean root rots are a serious problem in the area (8) and Fusarium root rot caused by $F$. solani $\mathrm{f}$. sp. phaseoli is one of the major pathogens (5).

North Dakota and northern Minnesota constitute the most northerly soybean and dry bean production area in the United States, with about 5 million acres of these crops. The most northerly occurrence of SCN is also in this area. The cold soil temperatures in the tillage layer in this region, which average $-1^{\circ} \mathrm{C}$ over 6 months of the year (data from the North Dakota agricultural weather network: http://ndawn.ndsu. nodak.edu/), favor SCN survival because microbial degradation of eggs is minimized. Studies of SCN reproduction on soybean and survival in soil in North Dakota show that SCN reproduces at high levels on susceptible soybean cultivars and egg populations survive well during crop rotations to nonhosts (B. Nelson, unpublished data). SCN is spreading north and may eventually become a widespread and dominant soybean disease, as it has in other states. The dry bean industry should be aware of the potential threat to dry bean production. Research on the biology of SCN on dry bean and, specifically, on finding sources of resistance in Phaseolus vulgaris, such as Jaguar black bean, should be the focus of additional investigation into this potential threat.

\section{ACKNOWLEDGMENTS}

This research was supported by grants from the State Board of Agricultural Research and Education, North Dakota Soybean Council, and Northarvest Bean Growers Association. We thank T. Niblack and G. Tylka for training and advice on working with SCN.

\section{LITERATURE CITED}

1. Abawi, G. S., and Jacobsen, B. J. 1984. Effect of initial inoculum densities of Heterodera glycines on growth of soybean and kidney bean and their efficiency as hosts under greenhouse conditions. Phytopathology 74:14701474 .

2. Adeniji, M. O., Edwards, D. I., Sinclair, J. B., and Malek, R. B. 1975. Interrelationship of Heterodera glycines and Phytophthora megasperma var. sojae in soybeans. Phytopathology 65:722-725.

3. Anonymous. 2008. Agricultural Statistics Database. National Agricultural Statistics Service. United States Department of Agriculture. Online publication.

4. Becker, W. F., and Ferraz, S. 2004. Efeito da concentração inicial de inóculo do nematóide Heterodera glycines no desenvolvimento do feijoeiro comum. Rev. Agropecuaria Catarinense Florianópolis 17:89-93.

5. Bilgi, V. N., Bradley, C. A., Khot, S. D., Grafton, K. F., and Rasmussen, J. B. 2008. Response of dry bean genotypes to Fusarium root rot, caused by Fusarium solani f. sp. phaseoli, under field and greenhouse conditions. Plant Dis. 92:1197-1200.

6. Bradley, C. D., Biller, C. R., and Nelson, B. D. 2004. First report of soybean cyst nematodes (Heterodera glycines) on soybean in North Dakota. Plant Dis. 88:1287.

7. Fujita K., and Miura, O. 1934. On the parasitism of Heterodera schachtii Schmidt on beans. Trans. Sapporo Nat. Hist. Soc. 13:359-364.

8. Knodel, J. J., Bradley, C. A., Luecke, J. L., and Mars, G. A. 2007. 2004 and 2005 dry bean grower survey. N. D. State Univ. Ext. Rep. No. PP-1265.

9. McLean, K. S., and Lawrence, G. W. 1993. Interrelationship of Heterodera glycines and Fusarium solani in sudden death syndrome of soybean. J. Nematol. 25:434-439.

10. Melton, T. A, Jacobsen, B. J., and Noel, G. R. 1986. Effects of temperature on development of Heterodera glycines on Glycine max and Phaseolus vulgaris. J. Nematol. 18:468-474.

11. Melton, T. A., Noel, G. R., Jacobsen, B. J., and Hagedorn, D. J. 1985. Comparative host suitabilities of snap beans to the soybean cyst nematode (Heterodera glycines). Plant Dis. 69:119-122.

12. Niblack, T. L. 2005. Soybean cyst nematode management reconsidered. Plant Dis. 89:10201026.

13. Niblack, T. L., Arelli, P. R., Noel, G. R., Opperman, C. H., Orf., J. H., Schimtt, D. P., Shannon, J. G., and Tylka, G. L. 2002. A revised classification scheme for genetically diverse populations of Heterodera glycines. J. Nematol. 34:279-288.

14. Noel, G. R., Jacobsen, B. J., and Leeper, C. D. 1982. Soybean cyst nematode in commercial snap bean. Plant Dis. 66:520-522.

15. Poromarto, S., and Nelson, B. 2007. Soybean cyst nematode reproduction on navy, kidney, and black bean. (Abstr.) Phytopathology 97:S94.

16. Poromarto, S., and Nelson, B. 2007. Soybean cyst nematode reproduction on pinto bean. (Abstr.) Phytopathology 97:S163.

17. Poromarto, S., and Nelson, B. 2008. Effects of soybean cyst nematode on growth of pinto 
bean. (Abstr.) Phytopathology 98:S126.

18. Schmitt, D. P., and Shannon, G. 1992. Differentiating soybean responses to Heterodera glycines races. Crop Sci. 32:275-277.

19. Singh, S. P., Gepts, P., and Debouck, D. G. 1991. Races of common bean (Phaseolus vulgaris, Fabaceae). Econ. Bot. 45:379-396.

20. Smith, J. R., and Young, L. D. 2003. Host suitability of diverse lines of Phaseolus vulgaris to multiple populations of Heterodera glycines. J. Nematol. 35:23-28.

21. Tabor, G. M., Tylka, G. L., Behm, J. E., and Bronson, C. R. 2003. Heterodera glycines infection increases incidence and severity of brown stem rot in both resistant and susceptible soybean. Plant Dis. 87:655-661.
22. Wrather, J. A., and Koenning, S. R. 2006. Estimates of disease effects on soybean yields in the United States 2003 to 2005. J. Nematol. 38:173-180.

23. Xing, L., and Westphal, A. 2006. Interaction of Fusarium solani f. sp. glycines and Heterodera glycines in sudden death syndrome of soybean. Phytopathology 96:763-770. 